\title{
Rethinking success: Music in higher education
}

\begin{abstract}
Success, for the majority of performing arts majors, is defined as a performance career; and yet very few graduates achieve this goal. This paper draws on earlier research into the working lives and economic circumstances of instrumental musicians to consider how the goals of higher education music might be redefined for this cohort, and how this redefinition might be approached with students. Given the multiplicity of roles in which most musicians engage in order to sustain their careers, the research questions the concept of a musician as a performer, positing that a musician is rather someone who practises within the profession of music within one or more specialist fields. Whilst the paper considers instrumental music as its subject, the strategies for engaging students in future-focussed conversations have broad relevance.
\end{abstract}

\section{Background}

There is global debate concerning the effectiveness of education and training. In the arts this often concerns employability and graduate skills; globalisation; funding; cultural and public policy; and equity and engagement. Despite this dialogue and its relevance to the practice of musicians, music provides a useful example of just how narrowly graduate success is measured. In the US, for example, the College Music Society (CMS) and the National Association of Schools of Music (NASM) reported in 2000-2001 that just over half of music performance graduates were "gainfully employed" in music making (Campbell, 2001). In that same year there were 317,912 music students in the US, $42 \%$ of them performance majors (NASM, 2001). Combined CMS and NASM data suggests that $48 \%(64,091)$ of graduates were not employed in performance and would not therefore have been considered 'gainfully 
employed' (Bennett, 2007). Data from the UK, Europe, the US and Australia add to the pressure to equip graduates for more sustainable futures. At the institutional level, this often becomes a debate about the adequacy of existing curriculum.

Developing a curriculum that equips music graduates to build and sustain their careers has dominated the thinking of many institutions, particularly conservatoires, who have been described as "precariously poised between conserving the past and being swamped by the increasing constraints of public accountability" (Renshaw, in Lancaster, 2002, p. 2). In part this is because the realities of work within music are not well understood, which leaves institutions essentially designing a curriculum for the unknown (Bennett, 2008; Mills, 2005; Triantafyllaki, 2010).

In general terms, the broad range of skills required to sustain a career in the arts is fairly obvious. As Costantoura (2000, p. 65) suggests, success as a professional artist "involves at least the same suite of skills expected of any person who chooses to set up a small business". We can deduce that skills in business, organisational and communication will be vital, as will high-level practical skills and the ability to think creatively. Similar thinking has led conservatoires to introduce units in subjects such as teaching, community development, business, and entrepreneurship. The eclectic philosophy demonstrated by these initiatives is typical of the move towards a more multi-faceted curriculum. And yet in reality few of these initiatives reach the whole of the student population, the characteristics of musicians' work remain unclear, and what we know about musicians' work tells us that there is no way any degree program could equip students with everything they might ever need to know.

In order to position the argument that curricular change is insufficient to meet the goal of graduates who are equipped to forge sustainable careers, the following section presents summaries from a detailed study of musicians' work conducted between 2002 and 2005 (xxx, 2007). The study sought to create a retrospectively longitudinal picture of the careers of 
classically trained instrumental musicians, and to do this it employed three distinct but interrelated data collections within three sequential research phases. Identification of key concepts led to a pilot study (phase one) in which thirty-three interviews were conducted in Australia and in Europe. Data from these interviews informed the development and implementation of a survey (phase two), which addressed working lives, allocation of time, and education and training. A subsequent set of interviews conducted with musicians and educators living in Australia, the United States and Europe provided the basis for two indepth focus group interviews (phase three) within which significant themes were further explored.

Staying with the focus on classically trained instrumental musicians, findings from recent studies including the study described above, Metier in the UK (2001) and Traasdahl in Denmark (1996), concur that most musicians earn over half of their income from teachingrelated activities and that performance is most often a secondary role. Most musicians are wholly or partly self-employed, and they work in a variety of interdependent roles throughout their careers. Musicians tend to hold more than two music-related roles at any one time, and approximately one-third hold roles outside of music. Multiple roles are almost always present, both for freelance and company musicians, and very few musicians work solely in performance.

The 2007 study explored musicians' practice in terms of the percentage of time allocated to different roles. Of the $40 \%$ of musicians who were paid for all of their work, $42 \%$ cited performance as their primary role, $52 \%$ were primarily instrumental teachers and the remaining $6 \%$ held primarily administrative roles. Over $81 \%$ of respondents taught music in some form. Female musicians were much more likely to hold a primarily teaching role, and male musicians were more likely to work primarily in performance. The gendered differences were later explored in more depth (Bennett, 2008), but these issues remain in need of further 
research. Few musicians were found to engage solely with classical music: rather, musicians tended to be musically multi-lingual.

Almost $95 \%$ of the respondents had undertaken formal education and training, with the undergraduate Bachelor degree the most common program. Asked what changes they would make to their formal education and training, musicians spoke mostly about career development and industry experience (19.9\%); instrumental pedagogy (17.6\%); and (3) business skills (15.3\%). These three areas were also the most commonly mentioned professional development needs. Musicians advocated for students to be made aware of the realities of life as a musician, and to develop realistic goals. Musicians suggested that students should be taught communication skills, pedagogy, performance psychology, business skills, languages and physical fitness. Internships in a variety of settings were viewed as vital for skills development and career awareness.

The study concluded that far from making a living by making music, the majority of musicians finance music making by making a living: a musician typically works in one or more specialist fields, and builds a sustainable career by recognising and responding to the needs of their diverse communities. To do this, musicians need the skills to run a small business, create and manage new opportunities, and work in educational, ensemble and community settings.

It is at this point that the discussion would usually turn to the development of a curriculum that ensures graduate skills and attributes as suggested above. A broad base of skills, it would be argued, is essential for musicians to maximise available opportunities, manage their diverse practice, and access skilled work both within and outside of music. In the case of musicians the argument would most likely include the need for teacher training, preferably in a form that could provide credit towards a formal teaching qualification if required. Whilst these valid and important skills and attributes often underpin curricular reform, the personal and professional development of students is rarely taken into account. 
It has long been argued that graduate employability is a critical concern for all aspects of higher education. Not only does employability influence thinking about graduate destinations, transition programs, curricular reform and graduate attributes, "enhancing employability implies enhancing the quality of learning, teaching and assessment" (Knight and Yorke, 2004, p. 1). These aspects have received justifiable attention in recent years, and they have led to curricular reform similar to that described within the conservatoire setting. What hasn't been examined is whether the relevance of quality teaching, learning and assessments is clear to the student. What if, for example, individual characteristics of employability are poorly understood, defined or developed? How can these issues be resolved so that students can engage in a dialogue with their learning? Would this dialogue enable students to transform information and content into strategies and tools, and transform themselves from receivers of knowledge into participatory learners?

Musicians and artists are among a growing sector of the workforce within which casualisation and multiple roles are rife. In fact, the cultural workforce as a whole pre-empts employment trends in many countries. The traditional, linear career model has little relevance to the cultural sector, wherein people self-manage their careers in what have been described as protean careers, named after the mythological sea-god Proteus who was able to change form at will. Protean careerists expand their work behaviours, competencies and connections in search of success determined not in the eyes of others but in terms of self-identity, psychological success and the satisfaction of personal and professional needs. It is this intrinsic consideration of success aligned with vocation, calling or passion that suggests a different approach. Learning effectiveness relates directly to the development of students' self-schemas: 'possible selves' that represent what they might become, what they hope to become and what they fear becoming (Markus and Nurius, 1986). We can think of this in simple terms with two important points. 
First, the motivation to learn corresponds with students' conceptualisation of their strengths, interests and goals: their salient identities (Stryker, 1980). As Cross and Markus (1994, p. 434) point out, a salient identity "gives form, direction and self-relevant meaning to one's logical reasoning ability". In other words, students who believe they have skills in a particular domain perform better, have higher expectations for the future, pay greater attention, and stay on task. As teachers we recognise these as factors that underpin the extended learner effort and practice required to develop complex knowledge and skills.

Music performance majors have almost certainly been labelled as talented long before they enrol at university, and their commitment to the development of performance skills is an excellent example of extended learner effort and self-motivation. A degree of reluctance can be expected from undergraduate performance majors asked to expend valuable time acquiring the broader skills needed to sustain a career in music, especially when the intended career is in performance and the relevance of non-performance skills is not understood.

Second, the development of self-regulation and self-esteem are strongly related to envisioning the future self (Czikszentmihalyi \& Larson, 1984). For adolescents, this development often involves 'trying on' possible selves without a sense of permanence or expectation. However, higher education students are attempting to develop much more permanent self-structures as they negotiate potential career paths associated with their studies. It is for this reason that Feather (2000) emphasises the increasing need for young people to actively participate in life-career planning. This has considerable implications for how we teach courses that some students view as peripheral to their development. Beattie (2000, p. 17) draws attention to the timing of this participation, calling for students to "develop their own authentic voices at the outset of their professional education". Indeed, it is at each point of educational transition that students must re-identify with their learning and it is "a process that occurs over time" (Kift, 2009, Appendix 1). 
Career identity in the arts stems from students' aspirations and goals, and these are driven by a passion. For music students, the development of positive attitudes towards nonperformance study requires individual talents and interests to be thought of as personal strengths - as capacities rather than abilities. Students need opportunities to develop these strengths into realistic and achievable goals, and to reassess their goals and ambitions in light of many possible selves. These are possible futures based not on hierarchies of success, but on strengths, interests, personalities and lifestyle choices.

This approach of active knowing, or becoming, engages music students in planning a life in which music has a role, rather than preparing themselves for a career. And rather than teaching students to answer questions posed within the ideal curriculum, the approach challenges students to question the answers. Vocation and context, considered together at the individual level, are the triggers for students to engage in a level of complexity and uncertainty that equips them to create new and individual ways of thinking about their futures. In the end, reflexive and critical thinking underpins the individual and collective agency needed to negotiate the complex working life that characterises the protean life of a musician. 


\section{References}

Beattie, M. (2000). Narratives of Professional Learning: becoming a teacher and learning to teach. Journal of Education Enquiry, 1(2), 1-23.

Bennett, D. (2007). Utopia for music graduates. Is it achievable, and how should it be defined? British Journal of Music Education, 24(2), 179-189.

Bennett, D. (2008). A gendered study of the working patterns of classical musicians: Implications for practice. International Journal of Music Education, 26(1), 89-100.

Campbell, M. (2001, June). Music teacher education for this century: A working institute for change and innovation in our profession. Paper presented at the College Music Society Leadership Institute, Indianapolis, IL.

Cross, S.E., \& Markus, H.R. (1994). Self-Schemas, possible selves, and competent performance. Journal of Educational Psychology, 86(3), 423-438.

Czikszentmihalyi, M., \& Larson, R. (1984). Being adolescent: Conflict and growth in the teenage years, New York: Basic Books.

Costantoura, P. (2000). Australians and the Arts. Sydney, NSW: Australia Council.

Feather, F. (2000). Canada's best careers. Warwick, Toronto.

Kift, S. (2009). Articulating a transition pedagogy to scaffold and to enhance the first year learning experience in Australian higher education. Final report for the Australian Learning and Teaching Council. Retrieved January 26, 2010 from http://www.altc.edu.au/resources

Knight, P., \& Yorke, M. (2004). Learning, curriculum and employability in Higher Education. London: Routledge Farmer.

Lancaster, H. (2002). CONNECTing with: Editorial summary. Retrieved August 2, 2003, from http://www.gu.edu.au/school/qcgu/Connecting/content01_editorial_summary

Markus, H., \& Nurius, P. (1986). Positive selves. American Psychologist, 41(9), 954-969. Metier. (2001). AS2K: Arts skills 2000. London: Metier. 
Mills, J. (2005). Music in the school. Oxford: Oxford University Press.

National Association of Schools of Music (NASM). (2001). Music data summaries. Retrieved February 22, 2002, from http://heads.arts-accredit.org/index.jsp

Renshaw, P. (2002). Remaking the conservatorium agenda. Music Forum, 8(5), Retrieved March 18, 2004 from http://www.mca.org.au/mf2008renshaw.hml.

Stryker, S. (1980). Symbolic interactionism. Benjamin Cummings, California.

Traasdahl, J. O. (1996). Rhythmic music education in Denmark. In G. M. Oliva (Ed.), The ISME Commission for the Education of the Professional Musician 1996 seminar. The musician's role: New challenges (pp. 67-74). Lund: Universitetstryckeriet, Lund University.

Triantafyllaki, A. (2010). Performance teachers' identity and professional knowledge in advanced music teaching. Music Education Research, 12(1), 71-87. 